\title{
Memorandum on the Economic Situation
}

\author{
By Herbert Hoover \\ Director General of Relief; Executive Officer of the Supreme Economic Council and of the \\ American Relief Administration
}

\section{Demoralized Production in Europe}

$\mathrm{T}$ HE rehabilitation of Europe is immediately and primarily a European task but it is of tremendous concern to America and, for that matter, to the entire world. If America and the other countries of the world are to prosper, if civilization is to go forward rather than backward, Europe must get on her feet. She must rebuild and set up her industrial plant and put her men to producing the necessities of life. Although the chief part of this task of rehabilitation must be done by Europe herself, America must, temporarily at least, furnish her not only with food, raw materials, and equipment, but also with credit to finance the imports which she needs.

The economic difficulties of Europe as a whole at the signature of peace may be almost summarized in the phrase "demoralized productivity." The production of necessaries for the European population of $450,000,000$ (including Russia) has never been at so low an ebb as at this day.

A summary of the data in the records of the unemployment bureaus in Europe shows that 15 million families are receiving unemployment allowances in one form or another and are in the main being paid by a constant inflation of the currency. A rough estimate indicates that the population of Europe is at least 100 million greater than can be supported without imports and it must live by the production and distribution of exports. This situation is aggravated not only by lack of imports of raw materials but also by low production of European raw materials. Due to the same low production, Europe is today importing vast quantities of certain commodities which she formerly produced for herself and can again produce. Generally, not only is production far below even the level at the time of the signing of the armistice but far below what is necessary for the maintenance of life and health unless there shall be an unparalleled rate of import.

Even prior to the war, European peoples managed to produce from year to year but a trifling margin of commodities over what was necessary for consumption, plus what was necessary to export in exchange for essential imports. It is true that in pre-war times Europe managed to maintain armies and navies, together with a comparatively small class of nonproducers, and to gain slowly in physical improvements and investments abroad, but these luxuries and accumulations were only at the cost of a dangerously low standard of living to a very large number. The productivity of Europe in pre-war times had behind it the intensive stimulus of individualism and of a high state of economic discipline, and the density of population at all times responded closely to the resulting volume of production. During the war the intensive organization of economy in consumption, the patriotic stimulus to exertion and the addition of women to productive labor largely balanced the diver- 
sion of man power towar and munitions. These impulses have now been lost.

\section{Cause for Decreased Production}

It is not necessary to review at length the causes of this decrease of productivity. Chief among them are the following:

(1) The industrial and commercial demoralization arising originally out of the war but continued out of the struggle for political rearrangements during the armistice, the creation of new governments, and the inexperience and friction between these governments in the readjustment of economic relations.

(2) The proper and insistent demand of labor for higher standards of living and a voice in administration of their effort has unfortunately become impregnated with the theory that the limitation of effort below physical necessity will increase the total employment or improve their condition. Nor can it be overlooked that this particular line of defense by labor-no matter what its economic results may be - is to some degree the result of offensives against it.

(3) There is a great relaxation of effort as the reflex of the physical exhaustion of large sections of the populations from privation, and from the mental and physical strain of the war.

(4) To a minor degree, considering the whole volume, there has been a destruction of equipment and tools and loss of organization and skill due to war diversions in addition to a loss of man power. This latter is not at present pertinent in the face of present unemployment.

Results of Decreased Production The demoralization in production of coal in Europe today is an example in point of all these three forces mentioned above and promises a coal famine accompanied by industrial disaster unless remedied. It is due in part to the destruction of man power and the physical limitation of coal mines or their equipment. It is due in the largest degree, however, to the human factor of limitation of effort.

The continuation of the blockade after the armistice has undoubtedly destroyed enterprise even in open countries, and has of course prevented any recovery in enemy countries. The shortage in overseas transportation and the result of the uncertainties of the armistice upon international credits have checked the flow of raw materials and prevented recovery in the production of commodities especially needed for exchange for imports from overseas. The result of this delay has been unemployment, stagnation and absorption of capital in consumable commodities to some extent all over Europe.

From all these causes, accumulated to different intensity in different localities, there is the essential fact that unless productivity can be rapidly increased, there can be nothing but political, moral and economic chaos finally interpreting itself in loss of life on a scale hitherto undreamed.

\section{Economic Phenomena}

Reaction from strenuous economies.Coincident with this demoralization in production, other disastrous economic phenomena have developed, the principal one of which is that the very large wage-paid special workers and the large sums accumulated by speculation and manufacture during the war have raised the standard of living for many individuals from the level of mere 
necessities to a high level of luxuries. Among many other classes, also, there is a reaction from the strenuous economies against waste and the consumption of non-essentials in all countries. As a result there is today an outbreak of extravagance to a disheartening degree.

Higher Standard of Living.-Another economic change of favorable nature from a human point of view, but intensifying the problems of the moment, has been the rise in the standard of living in large sections of the working classes through the larger and better wage distribution, separation allowances, etc., during the war. Parallel with these classes are those of fixed income, the unorganized workers, and the unemployed upon whom the rising cost of living is inflicting the greatest hardship.

\section{Inability of the Western Hemis- phere to Rehabilitate Europe}

During some short period, it may be possible for the Western Hemisphere, which has retained and even increased its productivity, to supply the deficiencies of Europe. Such deficiencies, if met, will have to be supplied in large degree upon credits but aside from this the entire surplus productivity of the Western Hemisphere is totally incapable of meeting the present deficiency in European production if it is long continued. Nor, as a practical fact, can credits be mobilized for this purpose for more than a short period, because all credits must necessarily be simply advances against the return of commodities in exchange, and credits will break down the instant that the return of commodities becomes improbable. Further, if such credits be obtained for more than temporary purposes, they will result in the economic slavery of Europe to the Western
Hemisphere and the ultimate end will be war.

Consequently the solution of the problem, except in its purely temporary aspects, does not lie in a stream of commodities on credit from the Western Hemisphere, but lies in a vigorous realization of the actual situation in each country of Europe and a resolute statesmanship based on such a realization. The populations of Europe must be brought to a realization that productivity must be instantly increased.

\section{Demand for Economic Change in Status of Labor}

The outcome of social ferment and class consciousness is the most difficult of problems to solve. Growing out of the yearning for relief from the misery imposed by the war, and out of the sharp contrasts in degree of class suffering, especially in defeated countries, the demand for economic change in the status of labor has received a great stimulus leading to violence and revolution in large areas and a great impulse to radicalism in all others. In the main these movements have not infected the agricultural classes but are essentially an urban phenomenon.

In this ferment socialism, or communism has embraced to itself the claim to speak for all the down trodden, to bespeak human sympathy, to present remedies, and to be the lone voice of liberalism. Every economic patent medicine has been put under this banner. Europe is full of noisy denunciation of private property as necessarily being exploitation. Industrial labor, even in non-revolutionary countries, has put considerable reliance upon some degree of communism. Extremists are loud in asserting that production can be maintained by the impulse of altruism alone, instead of self-interest. 
Too often they are embracing criminal support and criminal methods to enforce their ideals of human betterment. Every country is engaged in political experimentation with varying degrees of these hypotheses, and thus far every trial has reduced production.

The Western Hemisphere with its more equitable division of property, its wider equality of opportunity, still believes that productivity rests on the stimulus from all the immutable human qualities of selfishness, self-interests, altruism, intelligence and education. It still believes that the remedy of economic wrong lies not in tampering with the delicate and highly developed organization of production and distribution, but in a better division of the profits arising from them. It still believes in the constitutional solution of these problems by the will of the majority, while Europe is drifting toward the domination of extremist minorities. The Western Hemisphere is still producing a surplus over its own needs.

The first and cardinal effort of European statesmanship must be to secure the materials and tools to labor, and to see that its men return to work. It must also secure a recognition of the fact that whatever the economic theory or political cry be, it must call for the maximum individual effort, for there is no margin of surplus productivity in Europe to risk in revolutionary experimentation. No economic policy that does not secure the maximum production will bring food to those stomachs or fuel to those hearths. There is no use of tears over rising prices! They are, to a great degree, a visualization of insufficient production.

Need for Conservation in ConSUMPTION

During the period of reconstruction and recovery from reduced productivity, the conservation in the consumption of non-essential commodities is more critical than at any time during the war. The relaxation of restriction on imports and on consumption of articles of this character since the armistice is disheartening. It finds its indication in the consumption of beverages and articles de luxe in many countries, increased even above a prewar normal. Never has there been such a necessity for the curtailment of luxury as exists today.

\section{Inflation of Currency}

The universal practice in all the countries at war of raising funds by inflation of currency is now bringing home its burden of trouble. In extreme cases the most resolute action must be taken, and at once. In other countries having a lesser degree of inflation, such currency must be reduced and included in the funded debt or, as an alternative, the costs of wages, living and international exchange must be expected to adjust themselves to this depression. The outcry against the high cost of living, the constant increase of wages and the fall in exchange that is going on are in a considerable degree due to this inevitable readjustment.

\section{Effect of Price Control on Pro- DUCTION}

The stimulation of production lies in the path of avoidance of all limitations upon the reward to the actual producer. In other words, attempts to control prices (otherwise than in the sense of control of vicious speculation) are the negation of stimulation to production, and can only result in further curtailment of the total of commodities available for the total number of 
human beings to be fed, clothed and housed. There still exist in Europe great bureaucracies, created from the necessity of control of prices and distribution by the conditions of the war, which are loath to recognize that, with world markets open, no such acute situation exists and that their continued existence is not essential except in the control of speculation.

The argument so much advanced, that world shortage may develop and that this justifies continued control of distribution and prices is based upon the fallacious assumption that even if the world markets are freed of restraint that there is a shortage today in many commodities so profound as to endanger health and life. From any present evidence, thanks to the high production outside of Europe, no shortage exists that will not find its quick remedy in diminished consumption or substitution of other commodities, through minor alteration and price. All attempts at international control of price, with a view to benefiting the population in Europe at the cost of the producer elsewhere, will inevitably produce retrogression in production in other parts of the world, the impact of which will be felt most in Europe. A decrease of 20 per cent of Western Hemisphere wheat would not starve the West; it would starve Europe. It must never be overlooked that control of prices and distribution cannot stop with a few prime commodities but, once started, its repercussions drive into a succeeding chain of commodities and that on the downward road of price control, there can be no stoppage until all commodities have been placed under restriction, with inevitable stifling of the total production. It is also often overlooked by the advocates of price control that, whereas the high level of production was maintained during the war even under a restraint of price, this high production was obtained by the most vivid appeal to patriotic impulse on both sides of the front. This stimulus to production and distribution no longer obtains and the world must go back to the prime motive, which is the reward to the individual producer and distributor.

That body of advocates who have deduced from war phenomena that production and distribution can be increased and maintained by appealing to altruism as the equivalent of patriotism or self-interest should observe the phenomena of Russia where the greatest food exporting country is today starving. It must be evident, also, that the production cannot increase if political incompetence continues in blockades, embargoes, censorship, mobilization, large armies, navies and war.

\section{Public Utilities}

There are certain foundations of industry in Europe that, no matter what the national or personal ownership or control may be, they yet partake of the nature of the public utilities in which other nations have a moral right. For instance, the discriminatory control of ships, railways, waterways, coal and iron in such a manner as to prevent the resumption of production by other states will inevitably debar economic recuperation and lead to local disputes and economic chaos with their ultimate infection abroad, to say nothing of the decrease in productivity. These abuses are already too evident.

Duty of the Western Hemisphere

The question of assistance from the Western Hemisphere during a certain 
temporary period, and the devotion of its limited surplus productivity to Europe, is a matter of importance and one that requires statesmanlike handling and vision. Although it is important, it is but a minor question compared to those stated above and it is in a great degree dependent upon the proper solution of the factors already touched upon. It is a service that America must approach in a high sense of human duty and sympathy. This service will, however, be best performed by the insistence that aid will not be forthcoming to any country that does not resolutely set in order its internal financial and political situations, that does not devote itself to the increase of productivity, that does not curtail consumption of luxuries and the expenditure upon armament and that does not cease hostilities and treat its neighbors fairly. If these conditions are complied with, it will be the duty of America and all the Western Hemisphere to put forth every possible effort to tide Europe over this period of temporary economic difficulty. Without the fulfilment of these conditions, the effort is hopeless.

With Europe turned toward peace, however, with her skill and labor alligned to overcome the terrible accumulation of difficulties the economic burden upon the West should not last over a year and can be carried and will be repaid. To effect these results the resources of Europe and also those of the Americas must be mobilized. 